\title{
Socio-economic contributions of forest products to livelihoods in Yewa north local government ogun State Nigeria
}

\author{
Akinyode Olawumi ${ }^{\mathrm{a} *}$, Esward Adeseye Alademerin ${ }^{\mathrm{b}}$, Sikiru Oluwole Banjo ${ }^{\mathrm{c}}$, Rachel Ijisekan ${ }^{\mathrm{c}}$ \\ a Tai Solarin University of Education, Nigéria \\ ${ }^{\mathrm{b}}$ University of Eswatini, Southern Africa \\ c Tai Solarin University of Education, Nigeria \\ ${ }^{*}$ Corresponding author (aremutim@gmail.com)
}

\section{N F O}

Keywords

wild foods

conservation

household size

\section{Palavras-chaves}

alimentos silvestres conservação tamanho da família

\begin{abstract}
A B S T R A C T
The study assessed contributions of forest products to nutrition and livelihoods in Yewa North Local Government of Ogun State, Nigeria. The main objective of the study found out the socio-economic contributions of the forest foods towards livelihoods in Yewa North Local Government Area of Ogun State, Nigeria. The specific objectives; identified and described the socio-economic characteristics of the respondents, identified the available edible forest/wild plants and animals in the study area, determined the socio-economic factors influencing the use of forest foods in the study area as well as described major problems facing forest food collection, processing, marketing and consumption in the study area. Three hundred and fifty (350) respondents randomly selected from major communities were interviewed with questionnaire. Data generated were analysed using descriptive statistics and logistic regression. Majority (65\%) were males $(88 \%)$ between 21 and 60 years. The principal household size was 6-10 $(60 \%)$ persons; major occupation is farming (41\%). Farm sizes were below a hectare. Majority (75\%) lived in concrete houses and mud houses (22\%). About half $(45 \%)$ of the respondents uses water closets, pit latrines $(32 \%)$ while $20 \%$ defecated in nearby bushes. Ninety percent possessed mobile phones for communication and $68 \%$ indicated availability of conventional medical facilities. Drinkable water was sourced from private boreholes (31\%), public water $(46 \%)$, streams $(27 \%)$ and wells $(12 \%)$. The source of energy is national grid $(91 \%)$, kerosene stoves $(56 \%)$ and firewood $(28 \%)$. The respondents indicated high assets index in terms of household assets (81\%) and farm assets (92\%). Twenty-two plant species were identified of which $95 \%$ were eaten and twenty animal species were identified. Logistic regression model showed that sex and household size tended to increase the odds in favor of consumption of forest foods while age, educational farm size and tools owned tended to decrease consumption of forest foods. The principal problems confronting respondents were lack of storage facilities, poor transportation and shortage of wild foods during off seasons. The study concluded that forest products contribute significantly to livelihoods and recommends domestication and conservation.
\end{abstract}

\section{R E S U M O}

O estudo avaliou as contribuições de produtos florestais como meios de subsistência e nutrição no governo local de Yewa North do estado de Ogun, Nigéria. O objetivo principal do estudo foi descobri as contribuições socioeconômicas dos alimentos da floresta para a subsistência na área do governo local de Yewa North do estado de Ogun, na Nigéria. Os objetivos específicos: identificou e descreveu as características socioeconômicas dos entrevistados, identificou a floresta comestível/plantas selvagens e animais na área de estudo, determinou os fatores socioeconômicos que influenciam o uso de alimentos florestais na área de estudo, bem como descreveu os principais problemas enfrentados na coleta, processamento, comercialização e consumo de alimentos florestais na área de estudo. Trezentos e cinquenta (350) respondentes selecionados aleatoriamente nas principais comunidades foram entrevistados com questionário. Os dados gerados foram analisados por meio de estatística descritiva e regressão logística. A maioria (65\%) era do sexo masculino (88\%) entre 21 e 60 anos. O tamanho principal da família era de 6 a $10(60 \%)$ pessoas; a principal ocupação é a agricultura (41\%). O tamanho das fazendas estava abaixo de um hectare. A maioria (75\%) vivia em casas de concreto e casas de barro (22\%). Cerca de metade (45\%) dos entrevistados usa armários de água, latrinas (32\%) enquanto $20 \%$ defecam em arbustos próximos. Noventa por cento possuíam telefones celulares para comunicação e $68 \%$ indicaram disponibilidade de instalações médicas convencionais. A água potável provinha de furos de água privados (31\%), água pública $(46 \%)$, riachos $(27 \%)$ e poços $(12 \%)$. A fonte de energia é a rede nacional $(91 \%)$, fogões a querosene $(56 \%)$ e lenha (28\%). Os entrevistados indicaram alto índice de ativos em termos de ativos familiares $(81 \%)$ e ativos agrícolas (92\%). Vinte e duas espécies de plantas foram identificadas, das quais $95 \%$ foram comidas e vinte espécies de animais foram identificadas. O modelo de regressão logística mostrou que o sexo e o tamanho da família tendem a aumentar as chances em favor do consumo de alimentos da floresta, enquanto a idade, o tamanho da fazenda educacional e as ferramentas possuídas tendem a diminuir o consumo de alimentos da floresta. Os principais problemas enfrentados pelos entrevistados foram a falta de instalações de armazenamento, transporte deficiente e escassez de alimentos silvestres durante as férias. $\mathrm{O}$ estudo concluiu que os produtos florestais contribuem significativamente para a subsistência e recomenda domesticação e conservação.

Received 27 July 2020; Received in revised from 20 September 2020; Accepted 30 December 2020 


\section{INTRODUCTION}

Millions of households in the developing countries (Nigeria inclusive) depend on food and fodder from the forest to supplement their own diet and their livestock feeds. Forests are home to approximately $50-90 \%$ of all the world's terrestrial (land living), biodiversity- including for pollinators and wild relatives of many agricultural crops. (WWF Living planet Report, 2010). Globally, millions of people depend on the forest for their livelihoods - directly, through the consumption and sale of foods harvested in forests, and indirectly through forest-related employment and income generation, forest ecosystem services and forest biodiversity. An estimated 2.6 billion people rely on fuel wood including charcoal for cooking their foods (FAO, 2013). Forest food make significant direct contribution to the food security of rural population providing vast array of foods which supply essential nutrients especially at times when other food sources are unavailable. The contribution of wild fruits, nuts, seeds, vegetables and other classes of forest edible products to the local diet in developing countries and their potential in overcoming or ameliorating prevailing foods problems are enormous. In many instances, the distribution between food and medicine is not clear cut. Many edible plants from the forest are used in traditional medicine

This study showed the link between edible forest foods and food security. Nonetheless, information which are available suggest that contributions from forest foods regarding health and nutritional values are very important.

In developing countries such as Nigeria most of its rural community depends on Non-Timber Forest Products (NTFPs) for some or all of it nutritional, income, health and raw material needs. In some cases, NTFPs are the only sources of income for some rural communities (Wollenberg and Septiani, 1998) and they form an integral part of rural economy which enables them to have the resources and ability to access and purchase their required household food demand. Jimoh (2006) reported that in Nigeria, NTFPs contribute significantly to household income and forest security and this plays an important role in poverty reduction and the problems of food insecurity. Non-timber forest products (NTFPs) contribute sustainably to nutrition either as parts of the family diet or as means to achieve household food security by serving as a means to achieve income generation that will empower the household to purchase their required household diet demands (FAO, 1995, Shackleton and Shackleton, 2004).

Rural households across the world have various reasons for which they engage in NTFPs gathering and these differ from one person to another. The world food summit of 1996 defined food security as existing when all persons at all times have access to sufficient, safe and nutritious food for the maintenance of a healthy life. This concept includes physical and economical access to food that meet people's dietary needs. This definition was built on three fundamental principles which are: Food access: having sufficient funds or resources to obtain appropriate food for nutritious diet; Food availability: having sufficient quality of food available on a consistent basis and Food use: appropriate usage based on knowledge of basic nutrition and care.

The main objective of the study was to find out the socio-economic contributions of the forest foods towards livelihoods in Yewa North Local Government Area of Ogun State, Nigeria. The specific objectives; identified and described the socio-economic characteristics of the respondents, identified the available edible forest/wild plants and animals in the study area, determined the socioeconomic factors influencing the use of forest foods in the study area as well as described major problems facing forest food collection, processing, marketing and consumption in the study area.

\section{MATERIAL AND METHODS}

\section{The study area}

Yewa North Local Government Area of Ogun State is located in the derived savannah zone and it is one of the 20 Local Government Areas in Ogun State. It has a mean annual rainfall of about $1200 \mathrm{~mm}$ and mean monthly temperature of $10^{\circ} \mathrm{C}$ $24^{\circ} \mathrm{C}$ during rainy seasons and 30 Degree Celsius 35 Degree Celsius during the dry season. It is surrounded by Imeko Afon Local Government Area in the North, Yewa South Local Government Area in the South, Republic of Benin in the West and Abeokuta North Local Government Area in the East. It covers a land mass of $204,360 \mathrm{~km}^{2}$ with population of 228,970 based on 1991 population census figure (NPC, 1991). The estimated population in 2009 is 277,474 using $2.75 \%$ growth rate. The inhabitants are mainly Yorubas, speaking various local dialects and comprises of Yewa and Ketus. Their major occupation is farming and trading.

\section{Sources of data, sample size and sampling method}

Primary data was collected using questionnaire aided by personal interview of the respondents. The respondents were the forest users, that is, traditional 
medical practitioners, farmers, consumers and forest product sellers. Purposive random sampling technique was used to select fifty (50) respondents each from seven communities comprising of four (4) peri-urban (Aiyetoro, Oja-Odan, Igbogila and Ijoun) and three rural (Igan - Alade, Owode-ketu and Imasayi). This gave a total of 350 respondents. In conducting the survey, the researchers visited the study area and administer the questionnaire aided with personal interview for those who may not be able to read and write. The questionnaire copies were retrieved within two days of administering to the literate respondents while non-literate respondents were interviewed and their responses were recorded immediately in the questionnaire which is taken away by the researcher on the spot.

\section{Data Analysis Techniques:}

1. Descriptive Statistics: The summaries of the socio-demographic characteristics of the respondents were collated presented using frequency counts and percentages.

2. Logistic Regression: was used to estimate the odds in favor or against the use/consumption of wild foods by the respondents. The formula is given as:

$$
\mathrm{F}(\mathrm{x})=\frac{1}{1+\ell^{-}}(\beta \mathrm{o}+\beta 1 \mathrm{x})
$$

Where $f(x)$ is ad probability of the dependent variable

$$
g(f(x))=\frac{\ln f(x)}{1-F(x)} \quad=\beta o+\beta 1 x
$$

or

$$
\frac{\mathrm{F}(\mathrm{x})}{1-\mathrm{f}(\mathrm{x})}=\ell^{\beta \mathrm{o}+\beta 1 \mathrm{x}}
$$

Where:

$\mathrm{g}(\mathrm{x})=$ the logit function

$g(f(x))=$ illustrates the logit i.e., $\log$ - odds or natural logarithm

$1_{\mathrm{n}} \quad=$ natural logarithm

$\mathrm{F}(\mathrm{x}) \quad=$ the probability that the dependent variable equals a case.

$\beta_{0}=$ the intercept from the linear regression equation (the value of the criterion

when the predictor is equal to zero.

$\beta 1 \mathrm{x}=$ the regression coefficient multiplied

by some value of the predictor base $\ell$

denotes the exponential function.

\section{RESULTS AND DISCUSSION}

The results of the various findings emanating from the analyses of the data generated from the field surveys and observations are presented using frequency tables, percentages and discussed for further clarification and understanding of the readers as well necessary implications for informed decision making.

Table 1 revealed that majority $(62 \%)$ of the respondents were males and about $38 \%$ were females, this implies male dominance among the respondents in the study area. It is worthy of note that female respondents (farmers), in addition to their agricultural activities, they are heavily involved in reproductive/domestic activities or roles such as cooking, caring for children as well as chores like fetching water and gathering firewood for cooking for their households and thus spends an average of 14-16 hours workday (Buckman and Holeegoah, 1993). In terms of age, $58 \%$ of the respondents were between 21-40 years, $29 \%$ were 41-60years. This implies that the larger percentage of the respondents were in their productive ages and thus helps in improving the standard of living of their households (Jibowo, 1998). A greater part (64\%) of the respondents were married while $36 \%$ were single. This indicated that the highest percentage of respondents were married individuals and matured to give credible responses. The respondents' educational qualifications included Senior Secondary School Certificate (45\%), Tertiary education (28\%), Primary school leaving certificate $(25 \%)$ and $2 \%$ are holders of other vocational/technical certificates. This implies that majority of the respondents were Senior Secondary School Certificate holders who due to financial constraint could not afford to further their education. Majority of the respondents $(62 \%)$ had 6-10 household members, $39 \%$ had 1-5 household members while $3 \%$ had $11-15$ household members. The overall implication of this is that majority of the respondents were people with enormous responsibilities. The major occupation of the respondents included farming (41\%), trading $(27 \%)$, civil service $(23 \%)$ and others not captured in the questionnaire (9\%). This implied that majority of the respondents were farmers and thus had adequate knowledge of the subject matter.

Non-Timber Forest Products are indispensable part of the livelihood strategy of communities living in and near forests and constitute important source of livelihood for millions of people across the world (Shaanker, Ganeshaiah, Krishnan, Rumya and Meera, 2004). 
Table 1 - Socio-economic characteristics of respondents.

\begin{tabular}{|c|c|c|}
\hline Variable & Frequency & Percentage \\
\hline \multicolumn{3}{|l|}{ Gender } \\
\hline Female & 133 & 38 \\
\hline Male & 217 & 62 \\
\hline \multicolumn{3}{|l|}{ Age } \\
\hline Below 20 & 32 & 9.14 \\
\hline $21-40$ & 203 & 58 \\
\hline $41-60$ & 105 & 30 \\
\hline Above 60 & 14 & 5 \\
\hline \multicolumn{3}{|l|}{ Marital status } \\
\hline Single & 122 & 34.86 \\
\hline Married & 228 & 65.14 \\
\hline \multicolumn{3}{|l|}{ Educational Qualification } \\
\hline $\begin{array}{l}\text { Primary School Certifi- } \\
\text { cate }\end{array}$ & 88 & 25.14 \\
\hline $\begin{array}{l}\text { Senior Secondary School } \\
\text { Certificate }\end{array}$ & 158 & 45.14 \\
\hline Tertiary & 98 & 28 \\
\hline Others & 6 & 1.72 \\
\hline \multicolumn{3}{|l|}{ Household size } \\
\hline $1-5$ & 105 & 30 \\
\hline $6-10$ & 217 & 62 \\
\hline $11-15$ & 28 & 8 \\
\hline \multicolumn{3}{|l|}{ Occupation } \\
\hline Farming & 140 & 40 \\
\hline Trading & 95 & 27.14 \\
\hline Civil servant & 68 & 19.43 \\
\hline Others & 86 & 13.43 \\
\hline
\end{tabular}

Table 2 showed that the land area put to farming by the respondents were less than 1 hectare $(85 \%)$. The implication is that most of these respondents operated at the subsistent level and depended on the collection of forest products as a means of improving their livelihoods which agrees with the findings of Wollenberg and Septiani (1998) that in some cases, NTFPs are the only sources of income for some rural communities. The respondents sourced their farmland through purchase (44\%), gift or inheritance $(28 \%)$, lease $(14 \%)$ and rent $(13 \%)$. This implies that the highest source of acquisition was purchase of the land and this had great implication for security of tenure on the land for sustainable livelihood diversification. The study revealed that $75 \%$ resided in concrete buildings, $22 \%$ resided in mud buildings, while 3\% lived in sheds. These results showed that majority of the respondents in the study area lived in concrete block buildings which further confirmed some level of civilization the community had attained. A greater part (51\%) lived in family houses, $42 \%$ in a self-owned building while $7 \%$ fell into those categories of houses not captured in the questionnaire such as rented apartment and makeshift buildings. About half (48\%) of the respondents used water closets, a quarter (32\%) used pit latrines, $20 \%$ used open defecation which had its attendant public health implications. The mode of communication according to the study showed that ninety percent $(90 \%)$ used mobile phones which is a modern system of effective communication to make them kept abreast of happening in the entire world. Majority (86\%) of the respondents used orthodox medical care while $14 \%$ used traditional medical care services. This implied that despite the agrarian nature of the community and their dispositions to various types of trees that are medicinal in nature, majority still prefer orthodox mode of medical care to traditional medical services. A quarter (31\%) of the respondents' sourced water from private bore holes, $30 \%$ from taps, $27 \%$ from streams while $12 \%$ sourced water from public bore holes. Further analysis shows that, $91 \%$ affirmed availability of electricity while $9 \%$ responded in the contrary. In terms of energy for cooking, $56 \%$ used kerosene stoves, $28 \%$ used firewood, $13 \%$ used electric stoves while $1 \%$ ) used charcoal. This showed that forest-based energy sources were not the principal source of energy for cooking and hence, not a threat to sustainable forest management in the study area.

Table 2 - Livelihood and household characteristic of respondents.

\begin{tabular}{|c|c|c|}
\hline Variable & Frequency & Percentage \\
\hline \multicolumn{3}{|l|}{ Farm size (Ha) } \\
\hline Below 1 & 127 & 85 \\
\hline Above 1 & 22 & 15 \\
\hline \multicolumn{3}{|c|}{ Farm land (Sources) } \\
\hline Lease & 21 & 14 \\
\hline Rent & 20 & 13 \\
\hline Purchase & 66 & 44 \\
\hline Gift (inherited) & 42 & 28 \\
\hline \multicolumn{3}{|l|}{ Type of residence } \\
\hline Mud & 33 & 22 \\
\hline Shed & 5 & 3 \\
\hline Concrete block & 111 & 75 \\
\hline \multicolumn{3}{|l|}{ House owned } \\
\hline Family house & 76 & 51 \\
\hline Self-owned & 62 & 42 \\
\hline Others & 11 & 7 \\
\hline \multicolumn{3}{|l|}{ Type of Toilet } \\
\hline Pit latrine & 48 & 32 \\
\hline Water closet & 72 & 48 \\
\hline None & 29 & 20 \\
\hline \multicolumn{3}{|c|}{ Communication system } \\
\hline Mobile phone & 134 & 90 \\
\hline Post Office Box & 6 & 4 \\
\hline None & 9 & 6 \\
\hline \multicolumn{3}{|l|}{ Medical care } \\
\hline Traditional & 21 & 14 \\
\hline Orthodox Western & 128 & 86 \\
\hline \multicolumn{3}{|l|}{ Source of water } \\
\hline Tap water & 44 & 30 \\
\hline Stream & 40 & 27 \\
\hline Well water & 18 & 12 \\
\hline Public bore hole & 23 & 16 \\
\hline Private bore hole & 46 & 31 \\
\hline \multicolumn{3}{|l|}{ Electricity } \\
\hline Yes & 135 & 91 \\
\hline No & 14 & 9 \\
\hline
\end{tabular}


Table 2 - Livelihood and household characteristic of respondents (continuation).

\begin{tabular}{lcc}
\hline \multicolumn{1}{c}{ Variable } & Frequency & Percentage \\
\hline Cooking material & & \\
Kerosene stove & 84 & 56 \\
Electric stove & 20 & 13 \\
Firewood & 41 & 28 \\
Coal & 2 & 1 \\
\hline
\end{tabular}

Table 3 shows that the respondents have high household and farm tool assets index of $81 \%$ and $92 \%$ respectively which indicates that they generally acquire more assets for productive purposes than for pleasure or leisure. They can therefore be said to have potential for expansion and better livelihood in the nearest future given necessary motivation and enabling environment by the government in the form of education, infrastructural development and offer of subsidies.

Table 3 - Household and farm asset index of respondents.

\begin{tabular}{lcc}
\multicolumn{1}{c}{ Variable } & Frequency & Percentage \\
\hline Household asset class & & \\
Low asset index & 70 & 20 \\
High asset index & 280 & 81 \\
\hline Farm tools asset class & & \\
Low asset owners & 28 & 8 \\
High asset owners & 322 & 92 \\
\hline
\end{tabular}

Table 4 showed that $71 \%$ of the respondents got mushroom from arable lands while $29 \%$ got theirs from the thick forests. Also, 99\% consumed mushroom while $1 \%$ used it for medicinal purposes. Majority (97\%) of the respondents cooked their mushroom while $3 \%$ of the respondents consumed it raw. Many $(85 \%)$ of the respondents indicated that mushroom was abundant while $15 \%$ indicated that it was rare. For cherry, $52 \%$ of the respondents found it in arable land and $48 \%$ sourced it in thick forests. Majority $(90 \%)$ of the respondents consumed cherry fruit while $10 \%$ used it for medicinal purposes. Many (72\%) took it raw while $28 \%$ cooked cherry fruit before use. Majority (77\%) of the respondents supported the fact that cherry fruit was abundant while $23 \%$ responded it was rare. The principal (92\%) source of bitter leaf was arable land while only $8 \%$ was found in thick forests. Majority $(88 \%)$ of the respondents consumed bitter leaf while $11 \%$ used it for medicinal purposes and $1 \%$ used it for other purposes. Many (77\%) of the respondents cooked bitter leaf, $17 \%$ squeezed or dry it before use while 5\% took it raw. Majority (97\%) indicated bitter leaf was abundant while only $3 \%$ said it was rare. For dandelion green, $90 \%$ of the respondents found it in arable land while 10\% found it in thick forests. Most (98\%) consumed dandelion green, $1 \%$ used it for medicinal purposes and $1 \%$ used it for other purposes. Majority (97\%) cooked it before use while 3\% used it raw. Many (95\%) of the respondent found dandelion green in abundance while $5 \%$ said it was rare. Also, $97 \%$ of the respondents found African spinach in arable land while $3 \%$ found it in thick forest. Majority (97\%) of the respondents consumed African spinach, $2 \%$ used it for medicinal purposes and $1 \%$ used it for other purposes. Majority (99\%) cooked it before use while just $1 \%$ used it raw. All $(100 \%)$ of the respondents said African spinach occurred in abundance. For Lagos spinach, 97\% of the respondents found it in arable land and 3\% found it in thick forests. Majority (97\%) of the respondents consumed Lagos spinach, $2 \%$ used it for medicinal purposes and $1 \%$ used it for other purposes. Many (97\%) cooked it before use while 3\% used it raw. The study showed that $100 \%$ of the respondents found Lagos spinach abundant in the study area. Principally (93\%) of Water leaf were found in arable land and only7\% were found in thick forests. Majority (97\%) of the respondents consumed water leaf, $2 \%$ used it for medicinal purposes and $1 \%$ used it for other purposes. Majority (99\%) cooked it before use while just $1 \%$ used it raw. All (100\%) of the respondents found water leaf abundantly in the study area. Majority (97\%) of the respondents found eggplant leaf in arable land and 3\% found it in thick forests. Also, $98 \%$ of the respondents consumed eggplant leaf, $(2 \%)$ used it for medicinal purposes. Majority (99\%) cooked it before use while only $1 \%$ used it raw. Majority (96\%) of the respondents found eggplant leaf abundant and four percent (4\%) said it was rare. For Malabar spinach, $96 \%$ of the respondents got it in arable land while only $4 \%$ ) found it in thick forests; $97 \%$ of the respondents consumed Malabar, while 3\% used it for medicinal purposes. Majority (98\%) cook it before use, $1 \%$ use it raw and $1 \%$ process it using various methods. For African basil, 95\% of the respondents found it in arable land and 5\% found it in thick forests. A larger part $73 \%$ used African basil for food, $23 \%$ used it for medicinal purposes while $4 \%$ used it for other purposes. Many (65\%) cooked African basil, $28 \%$ squeezed or dried it before use while $7 \%$ took it raw. Majority (97\%) of the respondents found African basil in abundance while only $1 \%$ said it was rare. For Bologi, $97 \%$ of the respondents got it in arable lands while 3\% got it on thick forests. Majority (93\%) of the respondents used Bologi for food, $5 \%$ used it as medicine while $1 \%$ used for other purposes. Majority (97\%) of the respondents cooked Bologi before eating it, $3 \%$ either dried it or processed it through other means. According to the table, Bologi leaves were abundant $(87 \%)$ and rare $(13 \%)$. Majority $(91 \%)$ of pumpkin leaf was from the arable land while only $8 \%$ was from the thick forests. Many (93\%) of the respondents 
used pumpkin leaves for food, $5 \%$ used it for medicinal purpose while $2 \%$ used it for other purposes not mentioned; $95 \%$ of the respondents cooked pumpkin leaf before consumption, $4 \%$ squeezed or dried it while $1 \%$ took it raw. Pumpkin leaf was $94 \%$ abundant in the area of study and $6 \%$ rare. In another vein, $76 \%$ of Mango was found in arable lands while $24 \%$ was found in thick forests. Majority $(83 \%)$ consumed mango, $16 \%$ used it for medicinal purposes while $1 \%$ used it for other reasons not mentioned. Majority (83\%) of the respondents took it raw, $16 \%$ cooked mango before taking and $1 \%$ took it through other means. Mango was $88 \%$ abundant and $12 \%$ rare in the study area. Like Mango, Cashew is found mostly in arable land $(52 \%)$ and in thick forests (48\%). Majority (84\%) of the respondents used cashew as food while $15 \%$ used it for medicinal purposes and $1 \%$ used it for other things not mentioned. Many $(81 \%)$ consumed it raw while $19 \%$ cook cashew before eating it. This showed that cashew can be used in different ways. And, that different parts of cashew could be taken differently. Cashew is $80 \%$ abundant and $20 \%$ rare. For Kolanut, (68\%) of the respondents found it in thick forests and $32 \%$ arable land. This proved that the larger percentage of Kolanut were found in the thick forests. Majority (77\%) of the respondents took Kolanut as food, $22 \%$ used it for medicinal purposes while $1 \%$ used Kolanut in other ways not mentioned. Majority (85\%) took it raw, $14 \%$ processed or cooked Kolanut before consumption, while $1 \%$ took or used it through other means. Kolanut is $79 \%$ abundant and $22 \%$ rare. In table $576 \%$ of the respondents get sheanut from the thick forests while $26 \%$ get it from arable land. Some (41\%) of the respondents use sheanut for food, $32 \%$ doesn't know what it is used for while $27 \%$ used it for medicinal purposes. Many (52\%) used it raw, $36 \%$ process it through other means while $11 \%$ cooked or steam sheanut before use. Sheanut is $80 \%$ rare and $20 \%$ abundant. This explained why so many of the respondents couldn't explain its uses and processes.

For palm fruit, $67 \%$ of it was from thick forests while $32 \%$ was from arable land. Majority (70\%) of the respondents used palm fruit for food, $18 \%$ use it for medicinal purposes while $12 \%$ used it for other purposes. Larger percent (68\%) cooked palm fruit before consumption, 27\%) consumed it raw while $5 \%$ process it in other ways not mentioned. Palm fruit in the area of study is $81 \%$ abundant and $19 \%$ rare. This implies that palm fruit is present in the study area in large quantities. For Walnut, $83 \%$ of it is gotten from thick forests while $17 \%$ is gotten from arable land. Also, $98 \%$ eat walnut while $2 \%$ used it for medicinal purposes; $54 \%$ cooks it before eating while $46 \%$ ate it raw. Walnut is $86 \%$ rare and
$14 \%$ abundant in the study area. This implies that walnut is almost not available in the study area.

Guava is found in thick forests (73\%) and arable lands (27\%). Majority (96\%) of the respondents eat guava while $4 \%$ use it for medicinal purposes. Many $(89 \%)$ eat guava raw while $11 \%$ cook it before eating. Majority (89\%) of the respondents said that guava is abundant while $12 \%$ said it is rare. For Ackee $(79 \%)$ of it is found in thick forests while $21 \%$ is found in arable land and $93 \%$ eat Ackee therefore it is used as food, $6 \%$ use it for medicinal purposes while $1 \%$ used it for other not mentioned. Similarly, $91 \%$ eat it raw, $8 \%$ cook Ackee before consumption while $1 \%$ process it through other means not mentioned before use. Majority (88\%) of the respondents said that Ackee is abundant while $12 \%$ said it is rare. This parameter show that Ackee is abundantly consumed in the study area.

According to the respondents, eighty-one (81\%) found Dialium indum in thick forest while $20 \%$ found it in arable land. Majority (95\%) of the respondents eat (consume as food) Dialium indum, $4 \%$ used it for medicinal purposes while $1 \%$ used it for other purposes do not mention in this study; $91 \%$ eat it raw, $8 \%$ cook Dialium indum while $1 \%$ processed it through other means. Dialium indum is (89\%) abundant and $11 \%$ rare.

The above findings are in agreement with the assertion of Jimoh (2006) that in Nigeria, Non-Timber Forest Products (NTFPs) contribute significantly to household income and forest security and this plays an important role in poverty reduction and the problems of food insecurity. Given that most respondents collect and eat forest fruits, a good knowledge and practice of re-greening through agroforestry is expected to boost not only their farm productivity, diet diversity and adequate nutrition but eventually lead to poverty reduction as reported by Irz, et. al. (2002). A general look at the principal sources of the forest plants foods is the thick forest. The importance of forest products especially trees include raw materials for industry (like wood, fibres, ropes, baskets, clothing, etc.), food for people (fruits, nuts, oils, pods, honey, barks, etc.). feed for livestock, energy (firewood, charcoal, sawdust/chips, etc.) and other services such as shade for people, shelterbelts and soil fertility replenishment (Musukwe and Mbalule, 2001) and, hence, the lifelong importance of forest in human and animal survival as well as biodiversity management cannot be overemphasized.

The general confirmation by respondents (above $90 \%$ ) that most of the wild plant foods are available in abundance is a confirmation a previous study by Sodiya, et al., (2017) that fruits are readily and abundantly available all over the villages surveyed in Odeda Local Government Area of Ogun State. 
Table 4 - Identified wild edible plant foods.

\begin{tabular}{|c|c|c|c|c|c|c|c|c|c|c|c|}
\hline \multirow{2}{*}{ Local Name } & \multirow{2}{*}{ Botanical Name } & \multicolumn{2}{|c|}{ Habitat } & \multicolumn{3}{|c|}{ Uses } & \multicolumn{3}{|c|}{ Processing } & \multicolumn{2}{|c|}{ Occurrence } \\
\hline & & Ar. & TF & $\mathbf{F}$ & $\mathbf{M}$ & $\mathbf{O}$ & $\mathbf{C}$ & $\mathbf{R}$ & S/D/A & $\mathbf{A}$ & $\mathbf{R}$ \\
\hline Mushroom & Agaricus bisporus & & & & & & & & & & \\
\hline Frequency & & 105 & 44 & 148 & 1 & - & 145 & 4 & - & 127 & 22 \\
\hline Percentage & & 71 & 29 & 99 & 1 & - & 97 & 3 & - & 85 & 15 \\
\hline Cherry Fruits & Prunus avium & & & & & & & & & & \\
\hline Frequency & & 78 & 71 & 134 & 15 & - & 42 & 107 & - & 115 & 34 \\
\hline Percentage & & 52 & 48 & 90 & 10 & - & 28 & 72 & - & 77 & 23 \\
\hline Bitter Leaf & Vernonia amygdalina & & & & & & & & & & \\
\hline Frequency & & 137 & 12 & 131 & 16 & 2 & 115 & 8 & 26 & 145 & 4 \\
\hline Percentage & & 92 & 8 & 88 & 11 & 1 & 77 & 5 & 17 & 97 & 3 \\
\hline "Efo Yanrin" & Dandellion green & & & & & & & & & & \\
\hline Frequency & & 134 & 15 & 146 & 2 & 1 & 145 & 4 & - & 142 & 7 \\
\hline Pecentage & & 90 & 10 & 98 & 1 & 1 & 97 & 3 & - & 95 & 5 \\
\hline Afrcan Spinach & Amaranthus hybridus & & & & & & & & & & \\
\hline Frequency & & 145 & 4 & 145 & 3 & 1 & 147 & 2 & - & 149 & - \\
\hline Percentage & & 97 & 3 & 97 & 2 & 1 & 99 & 1 & - & 100 & - \\
\hline Lagos Spinach & Celosia argentea & & & & & & & & & & \\
\hline Frequency & & 145 & 4 & 145 & 3 & 1 & 145 & 4 & & & \\
\hline Percentage & & 97 & 3 & 97 & 2 & 1 & 97 & 3 & - & 149 & - \\
\hline Water Leaf & Talinum triangulare & & & & & & & & - & 100 & - \\
\hline Frequency & & 139 & 10 & 145 & 3 & 1 & 148 & 1 & - & 149 & - \\
\hline Perecntage & & 93 & 7 & 97 & 2 & 1 & 99 & 1 & - & 100 & - \\
\hline Egg Plant & Solanium macrocarpon & & & & & & & & & & \\
\hline Frequency & & 145 & 4 & 146 & 3 & - & 148 & 1 & - & 143 & 6 \\
\hline Percentage & & 97 & 3 & 98 & 2 & - & 99 & 1 & - & 96 & 4 \\
\hline Malabar Spinach & Baselia alba & & & & & & & & & & \\
\hline Frequency & & 143 & 6 & 145 & 4 & - & 147 & 1 & 1 & 147 & 2 \\
\hline Percentage & & 96 & 4 & 97 & 3 & - & 98 & 1 & 1 & 99 & 1 \\
\hline Afrcan Basil & Ocimum gratissimum & & & & & & & & & & \\
\hline Frequency & & 142 & 7 & 109 & 34 & 6 & 97 & 10 & 42 & 144 & 2 \\
\hline Percentage & & 95 & 5 & 73 & 23 & 4 & 65 & 7 & 28 & 97 & 1 \\
\hline Bologi & Solanecio biafrae & & & & & & & & & & \\
\hline Frequency & & 145 & 5 & 139 & 8 & 2 & 145 & 1 & 4 & 130 & 19 \\
\hline Percentage & & 97 & 3 & 93 & 5 & 1 & 97 & 1 & 3 & 87 & 13 \\
\hline Moringa & Moringa oleifera & & & & & & & & & & \\
\hline Frequency & & 135 & 14 & 139 & 7 & 3 & 142 & 2 & 5 & 140 & 9 \\
\hline Percentage & & 91 & 9 & 93 & 5 & 2 & 95 & 1 & 3 & 94 & 6 \\
\hline Mangoes & Mangifera indica & & & & & & & & & & \\
\hline Frequency & & 113 & 36 & 123 & 24 & 2 & 24 & 123 & 2 & 131 & 18 \\
\hline Percentage & & 76 & 24 & 83 & 16 & 1 & 16 & 83 & 1 & 88 & 12 \\
\hline Cashew & Anacardium occidentale & & & & & & & & & & \\
\hline Frequency & & 78 & 71 & 125 & 22 & 2 & 28 & 121 & - & 119 & 30 \\
\hline Percentage & & 52 & 48 & 84 & 15 & 1 & 19 & 81 & - & 80 & 20 \\
\hline Kolanut & Sterculiaceae colavera & & & & & & & & & & \\
\hline Frequency & & 48 & 101 & 115 & 32 & 2 & 21 & 127 & 1 & 117 & 32 \\
\hline Percentage & & 32 & 68 & 77 & 22 & 1 & 14 & 85 & 1 & 79 & 22 \\
\hline Sheanut & Butryospermum parkii & & & & & & & & & & \\
\hline Frequency & & 38 & 11 & 61 & 40 & 48 & 17 & 78 & 54 & 30 & 119 \\
\hline Percentage & & 26 & 76 & 41 & 27 & 32 & 11 & 52 & 36 & 20 & 80 \\
\hline Palm Fruit & Elaeis guineensis & & & & & & & & & & \\
\hline Frequency & & 47 & 100 & 104 & 27 & 18 & 101 & 40 & 8 & 121 & 28 \\
\hline Percentage & & 32 & 67 & 70 & 18 & 12 & 68 & 27 & 5 & 81 & 19 \\
\hline Walnut & Juglans regia & & & & & & & & & & \\
\hline Frequency & & 26 & 123 & 146 & 3 & - & 81 & 68 & - & 21 & 128 \\
\hline Percentage & & 17 & 83 & 98 & 2 & - & 54 & 46 & - & 14 & 86 \\
\hline Guava & Psidium uajava & & & & & & & & & & \\
\hline Frequency & & 40 & 109 & 143 & 6 & - & 17 & 132 & - & 123 & 16 \\
\hline Percentage & & 27 & 73 & 96 & 4 & - & 11 & 89 & - & 89 & 11 \\
\hline "Awin" & Dialium indum & & & & & & & & & & \\
\hline Frequency & & 29 & 120 & 141 & 6 & 2 & 12 & 136 & 1 & 132 & 17 \\
\hline Percentage & & 20 & 80 & 95 & 4 & 1 & 8 & 91 & 1 & 89 & 11 \\
\hline
\end{tabular}

Key: Habitat: Ar.= Arable Land, TF=Thick Forest; Uses: F= Food, M=Medicine, O= Others; Processing: R= Consumed Raw, C= Cooked, $\mathrm{S} / \mathrm{D} / \mathrm{A}=$ Squeeze/ Dry/ Alive; Occurrence: $\mathrm{A}=$ Available, $\mathrm{R}=$ Rare 
The table 5 shows the result of the survey on wild edible animal. The result explained the variables under habitat, uses, processing and their occurrence.

The table showed that ninety seven percent $(97 \%)$ of the monkey in the study area were found in thick forests, three percent (3\%) were found in arable land. Majority (94\%) of the respondent ate monkey, one percent $(1 \%)$ used it for medicine while 5\% used it for other things like sports or tourism. Majority (97\%) of the respondents cooked monkey before consumption, three percent $(3 \%)$ skin or dry it before use while one percent $(1 \%)$ eat or use monkey raw. Monkey is eighty nine percent (89\%) abundant and $11 \%$ rare.

Elephant according to ninety six percent $(96 \%)$ of the respondent is found in thick forests while three percent $(3 \%)$ found it in arable land. Many $(60 \%)$ of the respondents eat elephant, thirty-eight (38\%) use it for other while $1 \%$ use it for medicinal purposes. Forty nine percent (49\%) of the respondents cooked elephant before consumption, forty percent $(40 \%)$ either skin or dried before use while $11 \%$ use or consume elephant raw. Elephant is eighty nine percent $(89 \%)$ rare and $10 \%$ abundant. This implies that elephant is not available or is totally rare in the study area.

According to the respondents, seventy percent (70\%) of squirrel is found in thick forests while thirty percent $(30 \%)$ is found in arable land. Majority $(96 \%)$ of the respondents said that squirrel is used mainly for food, three percent (3\%) said it's for other uses not mentioned while $1 \%$ for medicinal reasons. many $(88 \%)$ of the respondents cook squirrel before eating, nine percent $(9 \%)$ use squirrel raw while $3 \%$ either skin or dry it before use. Squirrel is ninety two percent (92\%) abundant and $8 \%$ rare.

Bats are found in thick forests according to $65 \%$ of the respondent and $35 \%$ in arable land. Eighty seven percent $(87 \%)$ of the respondents eat bats, eight percent (8\%) use them for

medicinal reasons while $5 \%$ use them for other uses not mentioned. Majority ( $88 \%$ ) of the respondents cook bats before use or consumption, seven percent $(7 \%)$ use bats raw while $5 \%$ either skin or dry bats before use. Bats is $89 \%$ abundant and $11 \%$ rare.

For grasscutter fifty six percent $(56 \%)$ of the respondents get it from thick forests while forty four percent (44\%) found it in arable land. Majority (94\%) of the respondents said that grasscutters are for food while just $6 \%$ said it's for medicinal purpose. According to the study, $100 \%$ of the respondents agreed that grasscutters are cooked before use. Grasscutters are $89 \%$ abundant and $11 \%$ rare.

According to the respondents, sixty six percent
(66\%) of antelopes are found in thick forest while $34 \%$ are found in arable land. Majority (99\%) of the respondents eat antelopes while just $1 \%$ use it for medicinal purpose. Ninety eight percent $(98 \%)$ of the respondents cook antelopes before consumption and just $2 \%$ use it raw. Antelopes are $89 \%$ abundant and $11 \%$ rare.

Deer according to $73 \%$ of the respondents is found in thick forest while $27 \%$ found it in arable land. Majority (97\%) of deer according to the respondents are eating, one percent $(1 \%)$ use it for medicinal reasons while $2 \%$ use it for other uses not mentioned. Ninety five percent $(95 \%)$ of the respondents cook deer before consumption, three percent (3\%) either skin or dry it before use while $2 \%$ use it raw. Deer is $52 \%$ rare and $48 \%$ abundant.

For bee honey eighty ( $80 \%)$ of it is found in thick forests area while $20 \%$ is found in arable land. The study also shows that $73 \%$ of the respondents use bee honey for food, twenty-one (21\%) use it for medicinal purpose and six percent $(6 \%)$ use it for other purpose not mentioned in the study. Majority $(76 \%)$ of the respondent's harvest or extract bee honey before use, twenty one percent (21\%) cook bee honey while three (3\%) take it raw. Bee honey is $84 \%$ abundant and $16 \%$ rare.

The study showed that ninety five percent $(95 \%)$ of lions were found in thick forests while 5\% of the respondents said that Lions were found in arable land. Majority (85\%) doesn't know what lion is used for, thirteen percent (13\%) use Lion for food while two percent $(2 \%)$ use it for medicinal purposes. Eighty five percent $(85 \%)$ either skin or dry it before use, thirteen percent $(13 \%)$ of the respondents cook lion before use or consumption, $2 \%$ use it raw. Lion is $87 \%$ rare and $13 \%$ abundant. This implies that lion is not that available in the study area.

Snakes are found according to fifty percent (50\%) of the respondents in arable lands while 50\% is found in the thick forests. Majority (93\%) of the respondents eat snake, seven percent (7\%) use it for purposes not mentioned while $1 \%$ use it for medicinal purpose. Many (85\%) of the respondents cook snakes before use (eaten in most cases), nine percent $(9 \%)$ use it raw while six percent $(6 \%)$ either skin or dry it. Snakes are ninety one percent (91\%) abundant and $9 \%$ rare. This implies that snakes are many and is part of the forest food consumed in the study area.

For buffalo eighty seven percent (87\%) of the respondents find it in thick forests while thirteen percent (13\%) find it in arable land. Majority (74\%) of the respondents eat buffalo, twenty-four (24\%) of the respondents use it for other reasons not mentioned while $2 \%$ use it for medicinal purpose. Many (75\%) of the respondents cook buffalo before 
consumption, twenty three percent $(23 \%)$ either skin or dry it while three percent $(3 \%)$ use it raw. Buffalo is ninety percent $(90 \%)$ rare and $10 \%$ abundant. This implies that there is little or no buffalo in the study area.

Leopards according to ninety-three $(93 \%)$ of the respondents are found in thick forests while seven percent (7\%) said it is found in the arable land. Fifty seven percent (57\%) doesn't know what leopard is use for. Forty two percent (42\%) eat leopard while only one percent $(1 \%)$ use it for medicinal use. Sixty three percent $(63 \%)$ either skin or dry leopards before use, thirty four percent (34\%) of the respondents cook leopards, three percent (3\%) use it raw. Leopards are ninety five percent $(95 \%)$ rare and 5\% abundant. This implies that leopard is not part of the food animals in the study area.

The study shows that eighty two percent $(82 \%)$ of the respondents said that crocodile is found in thick forests while $18 \%$ found it in arable land. Majority $(71 \%)$ of the respondents eat crocodile, twenty eight percent $(28 \%)$ use it for some other reasons not mentioned while $1 \%$ use it for medicinal reasons. Many (71\%) of the respondents cook crocodile, twenty four percent (24\%) either skin or dry it while $5 \%$ use it raw. Crocodile is fifty nine percent (59\%) rare and $41 \%$ abundant.

For snail fifty four percent (54\%) of it is found in the arable land and forty six percent $(46 \%)$ is found in the thick forests. According to the respondents, eighty five percent $(85 \%)$ of the respondents eat snails, twelve percent (12\%) use it for medicinal reasons while $2 \%$ use it for other reasons not mentioned. Majority (86\%) of the respondents cook snail, thirteen percent (13\%) either skin or dry it before use while $1 \%$ use it raw. Snails are ninetytwo $(92 \%)$ abundant in the study area and seven percent $(7 \%)$ rare. Snails contribute largely to the food intake of the respondents in the study area.

Wolf according to seventy one percent $(71 \%)$ of the respondents is found in thick forests while twenty two percent (22\%) said it is found in arable land. Majority $(71 \%)$ of the respondents eat wolf, twenty six percent $(26 \%)$ use it for other reasons not mentioned while $3 \%$ use it for medicinal reasons. Many $(73 \%)$ of the respondents cook wolf, twenty six percent (26\%) use it for oth reasons not mentioned while $1 \%$ of the respondents use it raw (alive). Wolf is fifty seven percent (57\%) abundant and $43 \%$ rare.

According to the result fifty eight percent (58\%) of the respondents find toad or frog in arable land while forty two percent (42\%) find it from thick forests. Majority (94\%) of the respondents eat toad or frog, four percent (4\%) use it for other reasons not mentioned in the study while $2 \%$ use it for medicinal reasons. Majority (95\%) cook toad or frog,
$4 \%$ either skin or dry it while $1 \%$ use it raw. Toad or frog is ninety four percent (94\%) abundant and $6 \%$ rare in the study area.

The study shows that guinea fowl according to $52 \%$ of the respondents is found in arable land while $48 \%$ is found in the forest. Most (95\%) of the respondent eat guinea fowl, $4 \%$ use it for other reasons not mentioned while $1 \%$ use it for medicine. Majority (95\%) of the respondents cook guinea fowl, $4 \%$ use it for other purpose while $1 \%$ use it raw or alive. Guinea fowl is $94 \%$ abundant and $6 \%$ rare.

Boar according to $80 \%$ of the respondents is found in thick forests while $20 \%$ is found in arable land. Half (56\%) of the respondents eat boar, $40 \%$ use it for other purposes while $4 \%$ use it for medicine. Fifty five percent $(56 \%)$ of the respondents cook boar, $41 \%$ either skin or dry it before use while $3 \%$ use raw or alive. Boar is $91 \%$ rare and $9 \%$ abundant.

For Tiger ninety five percent $(95 \%)$ of it are found in thick forests while five percent (5\%) are found in the arable land. Seventy five percent (75\%) use it for other reasons not mentioned, fourteen percent (14\%) of the respondent eat tiger, $11 \%$ use it for medicine. Seventy four percent (74\%) either skin or dry it, fifteen percent $(15 \%)$ of the respondents cook tiger, $11 \%$ use it raw or alive. Tiger is said to be generally rare (98\%) and 2\% abundant. This implies that tiger is not part of the food consumption of the study area.

The study shows that Jaguar is found in the thick forests according to $93 \%$ of the respondents while $7 \%$ said it's found in the arable land. Eighty-six $(86 \%)$ use it for reasons not mentioned, $12 \%$ of the respondent eat jaguar, $2 \%$ use it for medicine. Eighty five percent (85\%) either skin or dry it, $14 \%$ of the respondents cook jaguar, $1 \%$ use it alive (raw). Jaguar is ninety seven percent (97\%) rare and $3 \%$ abundant.

A close look at the trends on the sources of the wild animal foods reveals that they are generally found in thick forests with only a few found in arable farms. This underscores the need to conserve available forest plantations as well as deliberate practice of agroforestry in the study area to ensure the continuous provision of the essential animal resources from the wild that helps in bridging the gaps in protein supply in the study area thereby ensuring improved protein nutrition as well as reduce child malnutrition in Nigeria (Shackleton and Shackleton, 2004; Hassan, Ikuenobe, Jalloh, Nelson and Thomas, 2013).

In a similar vein, most of the respondents indicated that apart from consuming the wild animals collected, they also make use of some of them in treating specific ailments peculiar to their area, or 
instance, snails is said to be used in boosting blood levels as well as in child delivery. This suggests the need for further ethnomedicinal investigations to ascertain the efficacy of some of these alternative therapies with a view to augmenting the orthodox medical practices that are grossly inadequate.

Table 5 - Identified wild edible animals.

\begin{tabular}{|c|c|c|c|c|c|c|c|c|c|c|c|}
\hline \multirow{2}{*}{ Local Name } & \multirow{2}{*}{ Botanical Name } & \multicolumn{2}{|c|}{ Habitat } & \multicolumn{3}{|c|}{ Uses } & \multicolumn{3}{|c|}{ Processing } & \multicolumn{2}{|c|}{ Occurrence } \\
\hline & & Ar. & TF & $\mathbf{F}$ & $\mathbf{M}$ & $\mathbf{O}$ & $\mathbf{C}$ & $\mathbf{R}$ & S/D/A & $\mathbf{A}$ & $\mathbf{R}$ \\
\hline Monkey & Macaca fascicularis & & & & & & & & & & \\
\hline Frequency & & 5 & 144 & 140 & 2 & 7 & 144 & 1 & 4 & 133 & 16 \\
\hline Percentage & & 3 & 97 & 94 & 1 & 5 & 97 & 1 & 3 & 89 & 11 \\
\hline Elephant & Loxodonta africana & & & & & & & & & & \\
\hline Frequency & & 4 & 144 & 90 & 1 & 57 & 73 & 16 & 60 & 15 & 133 \\
\hline Percentage & & 2.7 & 97 & 60 & 1 & 38 & 49 & 11 & 40 & 10 & 89 \\
\hline Squirrel & Sciurus carolinensis & & & & & & & & & & \\
\hline Frequency & & 45 & 104 & 143 & 1 & 5 & 131 & 14 & 4 & 137 & 12 \\
\hline Percentage & & 30 & 70 & 96 & 1 & 3 & 88 & 9 & 3 & 92 & 8 \\
\hline Bats & Tacca chantriers & & & & & & & & & & \\
\hline Frequency & & 52 & 97 & 129 & 12 & 8 & 131 & 10 & 8 & 133 & 16 \\
\hline Percentage & & 35 & 65 & 87 & 8 & 5 & 88 & 7 & 5 & 89 & 11 \\
\hline Grasscutter & Thryonomys swinderianus & & & & & & & & & & \\
\hline Frequency & & 65 & 84 & 140 & 9 & & 149 & & & 133 & 16 \\
\hline Percentage & & 44 & 56 & 94 & 6 & & 100 & & & 89 & 11 \\
\hline Antelopes & Annova reticulata & & & & & & & & & & \\
\hline Frequency & & 51 & 98 & 147 & 2 & & 146 & 3 & & 133 & 16 \\
\hline Percentage & & 34 & 66 & 99 & 1 & & 98 & 2 & & 89 & 11 \\
\hline Deer & Cervidae & & & & & & & & & & \\
\hline Frequency & & 40 & 109 & 144 & 2 & 3 & 142 & 3 & 4 & 71 & 78 \\
\hline Percentage & & 27 & 73 & 97 & 1 & 2 & 95 & 2 & 3 & 48 & 52 \\
\hline Bee honey & Apis mellifera & & & & & & & & & & \\
\hline Frequency & & 29 & 120 & 109 & 31 & 9 & 31 & 5 & 123 & 125 & 24 \\
\hline Percentage & & 19 & 81 & 73 & 21 & 6 & 21 & 3 & 76 & 84 & 16 \\
\hline Lion & Panthera leo & & & & & & & & & & \\
\hline Frequency & & 8 & 141 & 19 & 3 & 127 & 19 & 3 & 127 & 19 & 130 \\
\hline Percentage & & 5 & 95 & 13 & 2 & 85 & 13 & 2 & 85 & 13 & 87 \\
\hline Snakes & Venomous & & & & & & & & & & \\
\hline Frequency & & 74 & 75 & 138 & 1 & 10 & 126 & 14 & 9 & 135 & 14 \\
\hline Percentage & & 50 & 50 & 93 & 1 & 7 & 85 & 9 & 6 & 91 & 9 \\
\hline Buffalo & Bubalus arnee & & & & & & & & & & \\
\hline Frequency & & 20 & 129 & 110 & 3 & 36 & 111 & 4 & 34 & 15 & 134 \\
\hline Percentage & & 13 & 87 & 74 & 2 & 24 & 75 & 3 & 23 & 10 & 90 \\
\hline Leopard & Panthera pardius & & & & & & & & & & \\
\hline Frequency & & 10 & 139 & 62 & 2 & 85 & 51 & 4 & 94 & 7 & 142 \\
\hline Percentage & & 7 & 93 & 42 & 1 & 57 & 34 & 3 & 63 & 5 & 95 \\
\hline Crocodile & Crocodylus acutus & & & & & & & & & & \\
\hline Frequency & & 27 & 122 & 105 & 2 & 42 & 106 & 7 & 36 & 61 & 88 \\
\hline Percentage & & 18 & 82 & 71 & 1 & 28 & 71 & 5 & 24 & 41 & 59 \\
\hline Snail & Phylum mollusca & & & & & & & & & & \\
\hline Frequency & & 81 & 68 & 127 & 18 & 4 & 128 & 1 & 20 & 137 & 10 \\
\hline Percentage & & 54 & 46 & 85 & 12 & 2 & 86 & 1 & 13 & 92 & 7 \\
\hline Wolf & Canis lupus & & & & & & & & & & \\
\hline Frequency & & 32 & 117 & 105 & 5 & 39 & 109 & 1 & 39 & 85 & 64 \\
\hline Percentage & & 22 & 79 & 71 & 3 & 26 & 73 & 1 & 26 & 57 & 43 \\
\hline Toad or frog & Bufo bufo & & & & & & & & & & \\
\hline Frequency & & 86 & 63 & 140 & 3 & 6 & 142 & 1 & 6 & 140 & 9 \\
\hline Percentage & & 58 & 42 & 94 & 2 & 4 & 95 & 1 & 4 & 94 & 6 \\
\hline Guinea fowl & Numida Meleagris & & & & & & & & & & \\
\hline Frequency & & 71 & 78 & 146 & & 3 & 144 & 2 & 3 & 119 & 30 \\
\hline Percentage & & 48 & 52 & 98 & & 2 & 97 & 1 & 2 & 80 & 20 \\
\hline Boar & Sus scrofa & & & & & & & & & & \\
\hline Frequency & & 30 & 119 & 84 & 6 & 59 & 84 & 4 & 61 & 14 & 135 \\
\hline Percentage & & 20 & 80 & 56 & 4 & 40 & 56 & 3 & 41 & 9 & 91 \\
\hline
\end{tabular}


Table 5 - Identified wild edible animals (continuation).

\begin{tabular}{|c|c|c|c|c|c|c|c|c|c|c|c|}
\hline \multirow{2}{*}{ Local Name } & \multirow{2}{*}{ Botanical Name } & \multicolumn{2}{|c|}{ Habitat } & \multicolumn{3}{|c|}{ Uses } & \multicolumn{3}{|c|}{ Processing } & \multicolumn{2}{|c|}{ Occurrence } \\
\hline & & Ar. & TF & $\mathbf{F}$ & M & $\mathbf{O}$ & $\mathbf{C}$ & $\mathbf{R}$ & S/D/A & $\mathbf{A}$ & $\mathbf{R}$ \\
\hline Tiger & Panthera tigris & & & & & & & & & & \\
\hline Frequency & & 7 & 142 & 21 & 17 & 111 & 23 & 16 & 110 & 3 & 146 \\
\hline Percentage & & 5 & 95 & 14 & 11 & 75 & 15 & 11 & 74 & 2 & 98 \\
\hline Jaguar & Panthera once & & & & & & & & & & \\
\hline Frequency & & 6 & 139 & 18 & 3 & 128 & 21 & 2 & 126 & 4 & 145 \\
\hline Percentage & & 4 & 93 & 12 & 2 & 86 & 14 & 1 & 85 & 3 & 97 \\
\hline
\end{tabular}

Key: Habitat: Ar.= Arable Land, $\mathrm{TF}=$ Thick Forest, Uses: $\mathrm{F}=$ Food, $\mathrm{M}=$ Medicine, $\mathrm{O}=$ Others, Processing: $\mathrm{R}=\mathrm{Consumed} \mathrm{Raw,} \mathrm{C}=\mathrm{Cooked}$,

$\mathrm{S} / \mathrm{D} / \mathrm{A}=$ Squeeze/ Dry/ Alive, Occurrence: $\mathrm{A}=$ Available, $\mathrm{R}=$ Rare

Table 6 shows the results of the logistic regression of the determinants of the forest food consumption and the socio-economic characteristics of the respondents as they affect the odds in favor or against it in the study area. The model estimated explains about $43.7 \%$ of total variation in the dependent variable. This is evidenced from the CraggUnder R squared value of 0.437 . The estimated variables that significantly increased the odds in favor of consumption of forest foods are sex of the respondents and household size while age of respondents, educational attainment, farm size and the tools owned by the respondents decreased the odds in its favor. In other words, the respondents eat more of forest foods as based on their gender being male and as size of households increases while age, educational attainment, farm size and tools owned decreases the likelihood of eating forest foods among the respondents I the study area.

Table 6 - Logistic regression analysis of the deter min ants of forest food consumption in the study area.

\begin{tabular}{cccc}
\hline Variable name & Estimated coefficient & Standard error & T- ratio \\
\hline Sex & $0.15139 \mathrm{E}-01$ & 0.52294 & $0.2894 \mathrm{E}-01$ \\
Age & -0.18871 & 0.38270 & -0.49310 \\
Edu & $-0.65200 \mathrm{E}-01$ & 0.31023 & -0.21017 \\
Hhsz & 0.12216 & 0.14184 & 0.86123 \\
Farmsz & $-0.54758 \mathrm{E}-01$ & 0.13235 & -0.41373 \\
Toolsc & -0.16310 & 0.23708 & -0.68796 \\
Constant & 2.3740 & 1.8705 & 1.2692 \\
\hline
\end{tabular}

Scale factor $=0.14344 ;$ Cragg-uhler $=0.437 ;$ Log- likelihood function $=-59.616 ;$ Log of likehood ratio test $=1.71834$

\section{CONCLUSIONS}

The study concludes that forest products contributes significantly to livelihoods of respondents through improved nutrition and health maintenance. The study recommends domestication, conservation and proper management of available forest resources, education of the stakeholders on the sustainable harvesting and uses of beneficial wild products to forestall extinction. The results are invaluable for educative purposes for the people living in forest areas on the use of forest products and by products. The study revealed to a large extent how some of the forest resources hitherto not recognised as a source of money can be explored.

For the unemployed, exploring the forest of abundant resources can be a source to eke out a living and utilise so many of these products as food. Development of forest-based cottage industries can also emanate from the knowledge of this research output as diverse non-timber forest products have been identified with potential uses and that are available in commercial quantities. In another vein, the role of forest extension officers is germane to sustainable harvesting and utilisation of the identified forest resources to forestall overexploitation and or extinction of some of the very important plants and animal species.

\section{REFERENCES}

FAO. An analysis of socio-economic issues, 2013. (Available at: http/: www.fao.org/.../t612e02.htm).

FAO. Wildlife utilization and food security Africa. Rome; FAO. pp 1-8,1995.

Hassan SM, Ikuenose CE, Jalloh A, Nelson GC, Thomas TS. 2013. Nigeria; West African agriculture and climate change - a comprehensive analysis, chapter 10: 259-290. International Food Policy Research Institute, USA.

Irz X, Lin L, Thirtle C, Wiggins S. 2002. Agricultural productivity growth and poverty alleviation. Development Policy Review. vol.19 (4): 449-466.

Jibowo AA. 1998. Agricultural transformation; the secrete of national food surplus. An Inaugural Lecture Delivered on July $11^{\text {th }}$ at Tthe Obafemi Awolowo University, Ile Ife, Nigeria. 
Jimoh SO. Sustaining the roles of non-timber forest products in rural poverty reduction and household food security in nigeria. Journal of Fisheries International. v.1, n.2, p.6369,2006

Musukwe NW, Mbalule MI. 2001. Agroforestry, agriculture in Uganda Vol. III (Forestry); National Agricultural Research Organization, (Mukiibi, J.K, Eds.), Fountain Publishers, CTA/NARO, Chapter 2: p.34-47.

Shaanker KN, Ganeshaiah S, Krishnan R, Ramya, Meera C. 2004. Livelihood gains and ecological costs of non-timber forest products dependence". Assessing the roles of dependence, ecological knowledge, and marketing structure in three contrasting human and ecological settings in South India, Environmental Conservation. v.31, n.3, p.242-253.

Shackleton CM, Shackleton S. The importance of non-timber forest product in rural livelihood security and as safety net. A review of evidence from South Africa. South Africa journal of Science. pp.100-658, 2006.

Sodiya CI, Aromolaran AK, Alarima CI, Adubi KO, Armed AA, 2017. Involvement of rural youths in the marketing of non-timber forest products in odeda local government area, Ogun State, Nigeria, Annals of Child and Youth Studies, Aa Multidisplinary Academic Journal of the International Research and Development Network of the Children and Youth in Agriculture Programme in Nigeria (CYIAP-Network Publishing), pp.186-203.

Wollenberg E, Septiani NA. Estimating the incomes of people who depend on forest. In E. Wollenberg, A, Ingle (eds): Incomes and the forest products for local communities. Bogor: Centre for International Forestry Research. pp. 157$187,1998$. 